\title{
Purification of the $47 \mathrm{kDa}$ phosphoprotein associated with the NADPH oxidase of human neutrophils
}

\author{
Carmel G. TEAHAN, ${ }^{*} \ddagger$ Nick TOTTY, $\dagger$ Colin M. CASIMIR and Anthony W. SEGAL* \\ * Department of Medicine, University College London, The Rayne Institute, Faculty of Clinical Sciences, University Street, \\ London WC1E 6JJ, U.K., and † Ludwig Institute for Cancer Research, 91 Riding House Street, London W1P 8BT, U.K.
}

\begin{abstract}
A $47 \mathrm{kDa}$ protein in the cytosol of phagocytic cells becomes heavily phosphorylated and translocates to the cell membrane upon stimulation. This protein was isolated from the cytosol of human neutrophils by chromatography on ion-exchange and hydroxyapatite resins. Polyclonal antibodies to this protein demonstrated that it was present in the neutrophils of two patients with X-linked chronic granulomatous disease (CGD) but not in those of three patients with the autosomal recessive pattern of inheritance. A sequence of amino acids was determined from a tryptic peptide of this protein: GluMet-Phe-Pro-Ile-Glu-Ala-Gly-Ala-Ile-Asn-Xaa-Glu. This served to establish that the phosphoprotein isolated here is the same as a protein of a similar molecular mass identified by other workers. These studies confirm the involvement of this $47 \mathrm{kDa}$ phosphoprotein in the molecular pathology of autosomal recessive CGD and describe a method for the purification of the native protein.
\end{abstract}

\section{INTRODUCTION}

A microbicidal NADPH-dependent electron transport chain is present in neutrophils and other phagocytic cells. Phagocytosis is accompanied by a large increase in $\mathrm{O}_{2}$ consumption (the respiratory burst) which is important for microbial killing (Selvaraj \& Sbarra, 1966). Identification of some of the components of the NADPH oxidase has been facilitated by the study of neutrophils from patients with chronic granulomatous disease (CGD), in which the respiratory burst fails to be activated upon stimulation, and recurrent infections occur (Holmes et al., 1967). Cytochrome $b_{-245}$ was the first component of the oxidase to be identified (Segal et al., 1981; Roberts et al., 1982). It is thought to be the terminal component of the chain, donating electrons to $\mathrm{O}_{2}$. Its involvement in the oxidase was confirmed by its absence from the cells of patients with X-linked CGD, who account for approximately two-thirds of all CGD patients (Segal et al., 1983).

The majority of the remaining cases of CGD have an autosomal recessive form. Activation of the respiratory burst in normal cells is associated with the enhanced phosphorylation of several proteins, but autosomal recessive CGD is characterized by the absence of a prominent band of phosphorylation at $47 \mathrm{kDa}$ when stimulated ${ }^{32} \mathrm{P}$-labelled cells are electrophoresed on SDS/ polyacrylamide gels (Segal et al., 1985; Heyworth \& Segal, 1986; Kramer et al., 1988). Subsequently, by the method of Western blotting, it was discovered that about $90 \%$ of these patients demonstrate the absence of a protein of a similar molecular mass from their neutrophils (Nunoi et al., 1988; Clark et al., 1989).

We report the isolation of this $47 \mathrm{kDa}$ phosphoprotein from human neutrophils and demonstrate that this is the same as the $47 \mathrm{kDa}$ protein recently cloned by Lomax et al. (1989) and Volpp et al. (1989).

\section{EXPERIMENTAL}

\section{Preparation, labelling and fractionation of cells}

Neutrophils were prepared from the blood of healthy donors, from leukopheresis samples from patients with chronic granulo- cytic leukaemia (CGL) or from buffy coat residues obtained from the South London Blood Transfusion Centre, Tooting, London, U.K. (Segal \& Jones, 1980). Cells $\left[\left(5 \times 10^{7}\right)-\right.$ $\left.\left(5 \times 10^{8}\right) / \mathrm{ml}\right]$ were labelled with ${ }^{32} \mathrm{P}$, stimulated with phorbol 12-myristate 13-acetate (PMA) (Sigma, Poole, Dorset, U.K.), disrupted and fractionated as described previously (Heyworth et al., 1989). Cytosol and membranes were stored at $-70^{\circ} \mathrm{C}$.

\section{Electrophoresis, autoradiography and Western blotting}

SDS/PAGE [using 10\% (w/v) acrylamide] and subsequent autoradiography were performed as described by Heyworth \& Segal (1986). Mini-gels $(8 \mathrm{~cm} \times 7 \mathrm{~cm}$; Bio-Rad, Watford, Herts., U.K.) were used if gels were to be Western-blotted. Proteins were transferred from the gels on to $0.45 \mu \mathrm{m}$ nitrocellulose membranes (Schleicher and Schuell, Dassel, Germany) using an LKB 2117250 NOVABLOT blotting apparatus (Pharmacia LKB Biotechnology, Milton Keynes, Bucks., U.K.). Electrophoretic transfer was performed at $0.8 \mathrm{~mA} / \mathrm{cm}^{2}$ for $60-90 \mathrm{~min}$ in $25 \mathrm{mM}$ Tris $/ 192$ mm-glycine $/ 0.1 \%$ SDS $/ 4 \%$ methanol, pH 8.3. Proteins were revealed by staining with $0.02 \%$ Ponceau S (Sigma) for 1-2 min. The blots were rinsed in water and incubated for $60 \mathrm{~min}$ in blocking buffer [3\%(w/v) BSA, $10 \%(\mathrm{v} / \mathrm{v})$ normal goat serum, $1 \%(\mathrm{w} / \mathrm{v})$ gelatin, $0.1 \%(\mathrm{w} / \mathrm{v}) \mathrm{NaN}_{3}$ and $0.05 \%(\mathrm{v} / \mathrm{v})$ Tween 20 in $50 \mathrm{~mm}$-Tris $/ 20 \mathrm{~mm}-\mathrm{NaCl}$ (TBS), $\mathrm{pH}$ 7.4] and then in specific antibody at a dilution of $1: 100$ in blocking buffer overnight. The blots were rinsed for $60 \mathrm{~min}$ in five changes of TBS containing $0.05 \%(\mathrm{v} / \mathrm{v})$ Tween 20 and then incubated for 60 min in alkaline phosphatase-labelled goat anti-rabbit IgG at a dilution of 1:7500 in blocking buffer as recommended by the suppliers (Stratagene, La Jolla, CA, U.S.A.). The blots were washed in three changes of TBS/Tween for $30 \mathrm{~min}$ and then in two changes of TBS alone for a further $30 \mathrm{~min}$. Bound antibody was revealed by adding a mixture of Nitro Blue Tetrazolium and 5-bromo-4-chloro-3-indolyl phosphate according to the supplier's instructions (Stratagene).

\section{Purification of the $47 \mathrm{kDa}$ phosphoprotein}

All procedures were performed at $0-4{ }^{\circ} \mathrm{C} .{ }^{32} \mathrm{P}$-labelled cytosol

Abbreviations used: CGD, chronic granulomatous disease; CGL, chronic granulocytic leukaemia; PMA, phorbol 12-myristate 13-acetate; Tos-Lys$\mathrm{CHCl}_{2}$, tosyl-lysylchloromethane (' TLCK'); TBS, $50 \mathrm{mM}$-Tris/20 mM-NaCl; PBS, phosphate-buffered saline $\left(140 \mathrm{mM}-\mathrm{NaCl} / 9.2 \mathrm{mM}-\mathrm{Na}{ }_{2} \mathrm{HPO} /\right.$ $\left.1.3 \mathrm{mM}-\mathrm{NaH}_{2} \mathrm{PO}_{4}, \mathrm{pH} 7.4\right)$.

$\ddagger$ To whom correspondence should be addressed. 
prepared from $5 \times 10^{9}$ stimulated neutrophils (approx. $95 \mathrm{mg}$ of protein) was diluted $1: 4$ in $20 \mathrm{~mm}$-Tris/HCl/1 mM-EDTA/ $27 \mu$ M-tosyl-lysylchloromethane (Tos-Lys- $\mathrm{CH}_{2} \mathrm{Cl}$, Sigma)/100

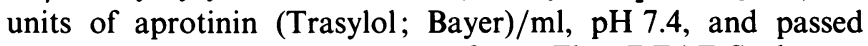
through a column $(1 \mathrm{~cm} \times 10 \mathrm{~cm})$ of Fast-Flow DEAE-Sepharose (Pharmacia) and a column $(1 \mathrm{~cm} \times 5 \mathrm{~cm})$ of Fast-Flow CMSepharose connected in series and equilibrated in Tris buffer,

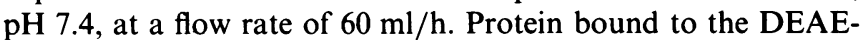
Sepharose was eluted with a $2 \mathrm{M}-\mathrm{NaCl}$ wash. This should not contain any of the $47 \mathrm{kDa}$ phosphoprotein. The $\mathrm{CM}$ gel was then equilibrated in $10 \mathrm{~mm}$-Mes, $1 \mathrm{~mm}-\mathrm{EGTA}, 27 \mu \mathrm{M}$-Tos-Lys- $\mathrm{CH}_{2} \mathrm{Cl}$ and 100 units of aprotinin $/ \mathrm{ml}, \mathrm{pH}$ 6.8. Protein was eluted from this column in two steps with six column vol. of $0.3 \mathrm{M}-\mathrm{NaCl}$ and six column vol. of $2 \mathrm{M}-\mathrm{NaCl}$ in Mes buffer. This particular buffer was used because it was found to result in a cleaner $47 \mathrm{kDa}$ fraction eluting from the CM-Sepharose than if $20 \mathrm{mM}$-Tris $/ \mathrm{HCl}$, $\mathrm{pH} 7.4$, was used. The $0.3 \mathrm{M}-\mathrm{NaCl}$ fraction was desalted on a PD-10 desalting column (Pharmacia) equilibrated in $10 \mathrm{~mm}$ sodium phosphate, $\mathrm{pH} 6.8$, including Tos- Lys- $\mathrm{CH}_{2} \mathrm{Cl}$ and aprotinin at the concentrations given above, and then applied on to a column of hydroxyapatite (DNA grade Bio-Gel HTP; BioRad) equilibrated in the same buffer (see Fig. 2 legend for running conditions). Protein was eluted with a gradient of sodium phosphate from $10 \mathrm{~mm}$ to $1 \mathrm{M}$. The $47 \mathrm{kDa}$ protein eluted between $0.2 \mathrm{M}$ - and $0.4 \mathrm{M}$-sodium phosphate. The entire purification was completed in 1 day where possible to minimize dephosphorylation of the $47 \mathrm{kDa}$ protein.

For larger preparations of protein the procedure was scaled up 10-fold using cytosol from CGL cells. Under these circumstances, the hydroxyapatite fraction was contaminated by other proteins. Further purification was achieved on a Mono $\mathrm{S}$ column (an f.p.l.c. cation exchanger from Pharmacia) in $50 \mathrm{~mm}-\mathrm{Mes}, \mathrm{pH}$ 5.5, including EGTA, Tos- $\mathrm{Lys}-\mathrm{CH}_{2} \mathrm{Cl}$ and aprotinin, at a flow rate of $60 \mathrm{ml} / \mathrm{h}$. Protein was eluted with a linear $\mathrm{NaCl}$ gradient $(0-1 \mathrm{M}-$ $\mathrm{NaCl})$.

\section{Amino acid sequencing}

Amino acid sequence analysis was performed using an Applied Biosystems model 477A amino acid sequencer equipped with a $120 \mathrm{~A}$ on-line phenylthiohydantoin amino acid analyser. Approx. $20 \mu \mathrm{g}$ of $47 \mathrm{kDa}$ protein was electroblotted and digested in situ with trypsin (Boehringer Mannheim, Lewes, E. Sussex, U.K.) using the method of Abersold et al. (1987). Resultant peptides were separated using reverse-phase h.p.l.c. on a Brownlee OD-300 column $(1 \mathrm{~mm} \times 100 \mathrm{~mm})$.

\section{Production of antibodies to the $47 \mathrm{kDa}$ protein}

The protein (about $200 \mu \mathrm{g}$ ) was eluted from $10 \%(\mathrm{w} / \mathrm{v})$ $\mathrm{SDS} /$ polyacrylamide gels in $0.4 \% \mathrm{NH}_{4} \mathrm{HCO}_{3} / 0.2 \% \mathrm{SDS} / 1 \mathrm{~mm}-$ dithiothreitol at $25 \mathrm{~V}$ overnight. The eluate was mixed with 4 vol. of ice-cold acetone and spun at $1400 \mathrm{~g}, 2^{\circ} \mathrm{C}$ for $10 \mathrm{~min}$. The supernatant was aspirated and the precipitate washed with icecold acetone and centrifuged as before. The precipitate was then dissolved in phosphate-buffered saline (PBS) and mixed with an equal volume of Freund's complete adjuvant (Difco Laboratories, Detroit, MI, U.S.A.) for the first injection (approx. $25 \mu \mathrm{g}$ of protein) and with Freund's incomplete adjuvant for the two booster injections (approx. $50 \mu \mathrm{g}$ each) at six subcutaneous sites in two New Zealand White rabbits.

\section{Protein estimation}

Protein was estimated by the BCA method as described by Pierce, Cambridge, U.K.

\section{Library screening}

A $\lambda$ gt1 1 cDNA expression library constructed from poly(A) ${ }^{+}$
RNA isolated from the HL60 promyelocytic leukaemia cell line, induced to differentiate with retinoic acid (kindly donated by $\mathrm{Dr}$ D. Bentley, Imperial Cancer Research Fund Laboratories, London, U.K.), was screened using the rabbit antiserum described above, at a dilution of $1: 100$, essentially as described by Huynh et al. (1985). Colonies binding specific antibody were revealed with an alkaline-phosphatase conjugated goat antirabbit second antibody, also as described previously. Positively reacting plaques were isolated and replated at a density of approx. 500 plaques per $90 \mathrm{~mm}$ Petri dish. The primary screening of about 200000 plaques yielded 14 original positives, of which ten re-screened as positive in the second cycle. These ten clones were purified to homogeneity and three were shown to contain specific sequences of the $47 \mathrm{kDa}$ phosphoprotein by hybridization in buffer containing $50 \%$ formamide (Wahl et al., 1979), for $16 \mathrm{~h}$ at $42{ }^{\circ} \mathrm{C}$, to a ${ }^{32} \mathrm{P}$-labelled, gel-purified, insert from a $47 \mathrm{kDa}$ phosphoprotein cDNA clone whose identity had been established by DNA sequence analysis (kindly donated by Dr. D. Bentley; see the Results and discussion section).

\section{RESULTS AND DISCUSSION}

The only method available for the identification of this protein was the characteristic mobility of the radiolabelled phosphoprotein on SDS/PAGE, and thus the purification was constrained by conditions that minimized dephosphorylation. These included the addition of fluoride to the cell-disruption buffer and the strict maintenance of the temperature below $4{ }^{\circ} \mathrm{C}$.

In early experiments the DEAE-Sepharose was equilibrated with buffer containing $20 \mathrm{mM}-\mathrm{NaF}$. However, it was found that this competed with protein for binding sites on the gel. When fluoride was omitted from the buffer, approx. $50 \%$ of the total protein was bound (Table 1), but the $47 \mathrm{kDa}$ protein did not bind. The inclusion of this step improved the resolution from the CM-Sepharose column to which the $47 \mathrm{kDa}$ protein bound at $\mathrm{pH}$ 6.8. It eluted from the $\mathrm{CM}$ between 0.15 and $0.3 \mathrm{M}-\mathrm{NaCl}$. To obtain maximum recovery and minimum dilution, a single $0.3 \mathrm{M}-$ $\mathrm{NaCl}$ elution step was employed routinely. At this stage the $47 \mathrm{kDa}$ band was the only clearly visible phosphorylated protein in the mixture (Fig. 1), with major non-phosphorylated bands at molecular masses of approx. $68 \mathrm{kDa}$ [possibly the same as that identified by Volpp et al. (1988) and Nunoi et al. (1988)] and $37 \mathrm{kDa}$. These contaminants were removed by chromatography on hydroxyapatite (Fig. 2). All the protein bound to the gel, with the $47 \mathrm{kDa}$ protein eluting earliest.

Polyclonal antibodies to the $47 \mathrm{kDa}$ band (see below) were used to determine whether the purification of the phosphorylated protein was also extracting the protein in its unphosphorylated state. Western blots of the material which bound to the DEAE-

Table 1. Purification of the $47 \mathrm{kDa}$ phosphoprotein

\begin{tabular}{|c|c|c|}
\hline \multirow[b]{2}{*}{ Fraction } & \multicolumn{2}{|c|}{ Protein } \\
\hline & (mg/10 $0^{9}$ cells) & $\begin{array}{c}(\% \text { of total } \\
\text { cytosolic protein })\end{array}$ \\
\hline Cytosol & $19.03 \pm 1.62$ & 100 \\
\hline $\begin{array}{l}\text { Unbound from DEAE- and } \\
\text { CM-Sepharose }\end{array}$ & $8.56 \pm 1.38$ & $44.5 \pm 7.2$ \\
\hline $\begin{array}{l}2 \mathrm{M}-\mathrm{NaCl} \text { eluate from } \\
\text { DEAE-Sepharose }\end{array}$ & $9.35 \pm 1.03$ & $46.5 \pm 4.1$ \\
\hline $\begin{array}{l}0.3 \mathrm{M}-\mathrm{NaCl} \text { eluate from } \mathrm{CM}- \\
\text { Sepharose }\end{array}$ & $0.71 \pm 0.03$ & $3.6 \pm 0.1$ \\
\hline $\begin{array}{l}2 \mathrm{M}-\mathrm{NaCl} \text { eluate from } \mathrm{CM} \text { - } \\
\text { Sepharose }\end{array}$ & $0.05 \pm 0.01$ & $0.27 \pm 0.05$ \\
\hline
\end{tabular}




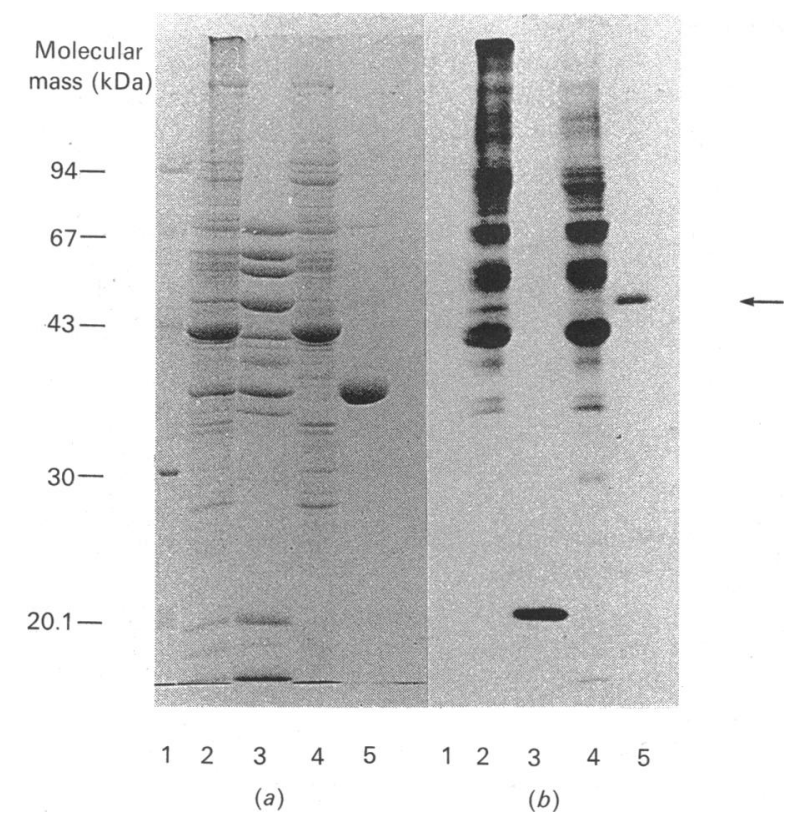

Fig. 1. Purification of $\mathbf{4 7} \mathrm{kDa}$ protein and identification on SDS/PAGE

(a) SDS/PAGE (10\% gels) of low molecular mass markers (lane 1), whole cytosol (lane 2), $2 \mathrm{M}-\mathrm{NaCl}$ eluate from DEAE-Sepharose (lane 3), unbound protein from DEAE- and CM-Sepharose (lane 4) and $0.3 \mathrm{M}-\mathrm{NaCl}$ eluate from CM-Sepharose (lane 5) (b) Corresponding autoradiograph of dried gel. The $47 \mathrm{kDa}$ band is indicated by the arrow.

Sepharose or passed through the CM-Sepharose column did not reveal protein which reacted with the anti- $47 \mathrm{kDa}$ serum, indicating that all the immunoreactive material co-purified with the phosphoprotein. In a small proportion of our preparations it was noted that a doublet, detected by both autoradiography and Western blotting, was present at the $47 \mathrm{kDa}$ position. This could result from proteolysis or from different degrees of phosphorylation.
A range of other chromatographic methods were investigated in the course of the work, and a summary of our findings is given in Table 2. The $47 \mathrm{kDa}$ protein, together with many other proteins, bound to both $2^{\prime} 5^{\prime}$ - and $3^{\prime} 5^{\prime}$-ADP-agarose. $\mathrm{NaCl}$ could be used for elution in both cases without loss of resolution. However, these substances were impractical for use on a large scale, and ion exchange was chosen as the first step in the purification because of the capacity of the gels and the high flow rates which could be used. Incorporation of ADP-agarose gels later on in the isolation procedure using gradient elution did not result in significant purification. Heparin-agarose was comparable with cation exchange in its resolving power, the latter being chosen because it gave somewhat more favourable results.

The results obtained with chromatofocusing were unsatisfactory, since it often proved difficult to detect the phosphoprotein in eluted fractions, and the $47 \mathrm{kDa}$ protein frequently trailed off the column. This observation is consistent with the wide spectrum of isoelectric points observed on two-dimensional gels (Kramer et al., 1988; Okamura et al., 1988a,b).

Hydrophobic interaction chromatography initially appeared promising. However, this method gave highly variable results, demonstrating extreme sensitivity to differences in the amount of protein loaded and the running temperature. In some experiments the $47 \mathrm{kDa}$ protein failed to elute from the gels. GTP-agarose did not bind the $47 \mathrm{kDa}$ protein when cytosol, diluted 1:4 in PBS, was applied. However, other workers have successfully used this affinity matrix to extract the protein using a different buffer system and eluting at $25^{\circ} \mathrm{C}$, at which temperature we observed rapid dephosphorylation (Volpp et al., 1988).

Antibody was detected in rabbit serum 3 weeks after the first booster injection. This antiserum was used to probe the protein on Western blots of cytosol from the cells of normal subjects and patients with $\mathrm{X}$-linked and autosomal recessive CGD. The protein was detected in the cytosol from both normal subjects and the patients with X-linked CGD but not from these with autosomal recessive CGD (Fig. 3). This confirmed that the $47 \mathrm{kDa}$ phosphoprotein is defective in these autosomal recessive CGD (Segal et al., 1985). It was also consistent with the observation of Volpp et al. (1988) that a protein of a similar
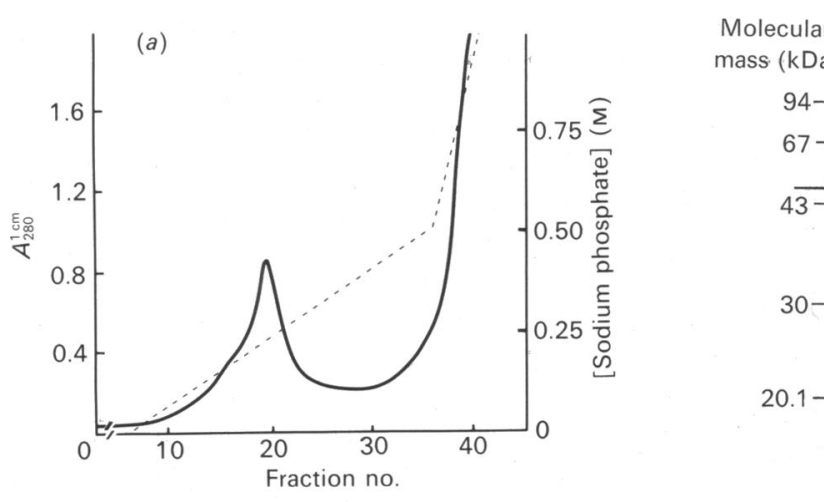

Fig. 2. Purification of $47 \mathrm{kDa}$ protein by chromatography on hydroxyapatite

(a) Elution of protein from hydroxyapatite gel. The $0.3 \mathrm{M}-\mathrm{NaCl}$ eluate (18 ml; approx. $3.5 \mathrm{mg}$ of protein) from CM-Sepharose was desalted as described in the Experimental section and a total volume of $25 \mathrm{ml}$ was loaded on to a column of hydroxyapatite $(0.5 \mathrm{~cm} \times 1.0 \mathrm{~cm})$ equilibrated in $10 \mathrm{~mm}$-sodium phosphate $/ 27 \mu \mathrm{M}$-Tos- $\mathrm{Lys}-\mathrm{CH}_{2} \mathrm{Cl} / 100$ units of aprotinin $/ \mathrm{ml}, \mathrm{pH} 6.8$, at a flow rate of $60 \mathrm{ml} / \mathrm{h}$ at $0^{\circ} \mathrm{C}$. Protein (-) was eluted with a linear gradient (---) of sodium phosphate, $\mathrm{pH} 6.8$, from $10 \mathrm{~mm}$ to $1 \mathrm{M}$. Fractions of $1 \mathrm{ml}$ were collected. (b) (i) SDS/PAGE (10\% slab gel) of column fractions. Fractions $(200 \mu \mathrm{l})$ were precipitated in $10 \%$ trichloroacetic acid and run. Lanes: a, low-molecular-mass markers; b, column sample; c, fractions $1-3$; d, fractions 4-7; e, fractions $8+9$; f, fractions $10+11 ; \mathrm{g}$, fractions $12+13$; h, fractions $14-17$; i, fractions $18-20$; , fractions $21+22 ; \mathrm{k}$, fractions $23+24 ; 1$, fractions $25-32 ; \mathrm{m}$, fractions $33-38 ; \mathrm{n}$, whole cytosol. (ii) Corresponding autoradiograph of dried gel. The $47 \mathrm{kDa}$ band is indicated by the arrows. 


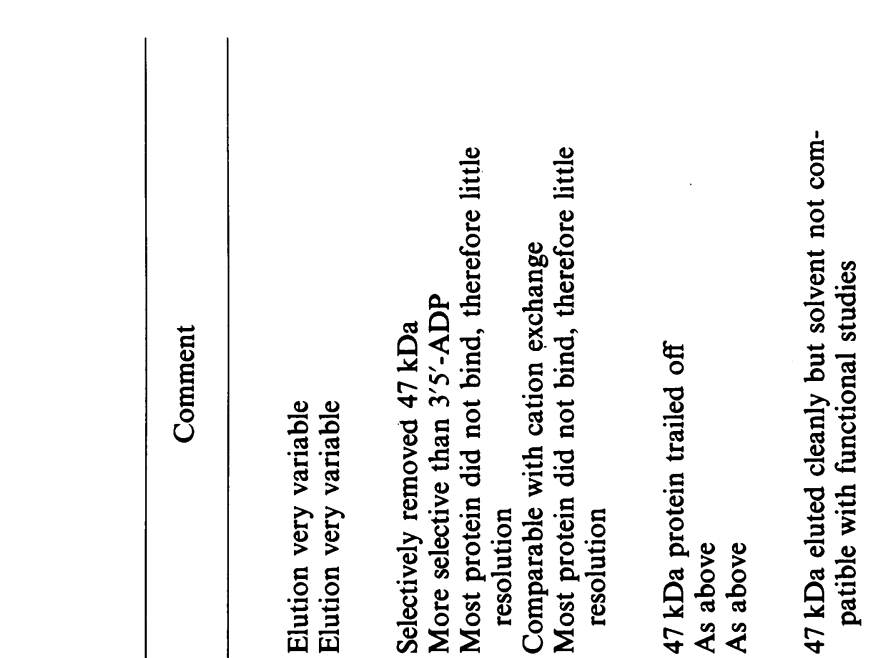

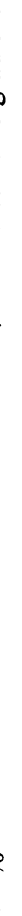

\begin{abstract}
with results of experiments by Kramer et al. (1988), which suggested that the protein was in fact present but failed to become phosphorylated. After we had screened a differentiationinduced HL60 cell $\lambda$ gt11 library with our antibodies, Lomax et al. (1989) and Volpp et al. (1989) reported the cDNA cloning and derived sequence of their $47 \mathrm{kDa}$ protein. To prove that the $47 \mathrm{kDa}$ phosphoprotein and the $47 \mathrm{kDa}$ protein whose gene was cloned were identical, we determined the amino acid sequence of a peptide purified from a tryptic digest of approx. $5 \mu \mathrm{g}$ of protein. The sequence: Glu-Met-Phe-Pro-Ile-Glu-Ala-Gly-AlaIle-Asn-Xaa-Glu corresponded to residues 56-68 of the protein sequence predicted from both cDNA sequences. The ten clones picked from the $\lambda$ gt11 library were hybridized against a probe prepared from a $47 \mathrm{kDa}$ phosphoprotein cDNA, independently cloned from a $\lambda$ gt 11 cDNA library and shown by its nucleotide sequence to contain a full-length cDNA insert (D. Bentley, Imperial Cancer Research Fund Laboratories, London). Three of these clones cross-hybridized with this probe at high stringency.

These studies confirm that the $47 \mathrm{kDa}$ protein initially described as abnormal in autosomal recessive CGD and that identified and cloned by. Volpp et al. $(1988,1989)$ and Lomax et al. (1989) through the production of antibodies to GTP-binding proteins are in fact the same. A method is described for the purification of this protein in its native state.
\end{abstract}

molecular mass was absent from these patients, but did not agree

Our thanks to Dr. David Bentley for his gift of the $\lambda \mathrm{gt} 11 \mathrm{cDNA}$ library and the cDNA close encoding the $47 \mathrm{kDa}$ phosphoprotein and for making the complete cDNA sequence available to us. We are grateful to The Wellcome Trust for financial support, to the staff of the Hammersmith Hospital, London and the Royal Marsden Hospital, Sutton for the supply of CGL cells and to the patients and their families for their co-operation in providing blood samples.

\title{
REFERENCES
}

Abersold, R., Leavitt, J., Saavedra, R., Hood, L. E. \& Kent, S. B. H. (1987) Proc. Natl. Acad. Sci. U.S.A. 84, 6970-6974

Clark, R. A., Malech, H. L., Gallin, J. I., Nunoi, H., Volpp, B. D., Pearson, D. W., Nauseef, W. M. \& Curnutte, J. T. (1989) N. Engl. J. Med. 321, 647-652

Heyworth, P. G. \& Segal, A. W. (1986) Biochem. J. 239, 723-731

Heyworth, P. G., Shrimpton, C. F. \& Segal, A. W. (1989) Biochem. J. 260, 243-248 
Holmes, B., Page, A. R. \& Good, R. A. (1967) J. Clin. Invest. 46, $1422-1432$

Huynh, T. V., Young, R. A. \& Davis, R. W. (1985) DNA Cloning (Glover, D. M., ed.), vol. 1, pp. 49-78, IRL Press, Oxford

Kramer, I. M., Verhoeven, A. J., van der Bend, R. L., Weening, R. S. \& Roos, D. (1988) J. Biol. Chem. 263, 2352-2357

Lomax, K. J., Leto, T. L., Nunoi, H., Gallin, J. I. \& Malech, H. L. (1989) Science 245, 409-412

Nunoi, H., Rotrosen, D., Gallin, J. I. \& Malech, H. L. (1988) Science 242, 1298-1301

Okamura, N., Malawista, S. E., Roberts, R. L., Rosen, H., Ochs, H. D., Babior, B. M. \& Curnutte, J. T. (1988a) Blood 72, 811-816

Okamura, N., Curnutte, J. T., Roberts, R. L. \& Babior, B. M. (1988b) J. Biol. Chem. 263, 6777-6782

Roberts, P. J., Cross, A. R., Jones, O. T. \& Segal, A. W. (1982) J. Cell. Biol. 95, 720-726
Segal, A. W. \& Jones, O. T. G. (1980) FEBS Lett. 110, 111-114

Segal, A. W., Garcia, R., Goldstone, H., Cross, A. R. \& Jones, O. T. (1981) Biochem. J. 196, 363-367

Segal, A. W., Cross, A. R., Garcia, R. C., Borregaard, N., Valerius, N. H., Soothill, J. F. \& Jones, O. T. (1983) N. Engl. J. Med. 308, 245-251

Segal, A. W., Heyworth, P. G., Cockcroft, S. \& Barrowman, M. M. (1985) Nature (London) 316, 547-549

Selvaraj, R. J. \& Sbarra, A. J. (1966) Nature (London) 211, 12721276

Volpp, B. D., Nauseef, W. M. \& Clark, R. A. (1988) Science 242, 1295-1297

Volpp, B. D., Nauseef, W. M., Donelson, J. E., Moser, D. R. \& Clark, R. A. (1989) Proc. Natl. Acad. Sci. U.S.A. 86, 7195-7199

Wahl, G. M., Stern, M. \& Stark, G. R. (1979) Proc. Natl. Acad. Sci. U.S.A 76, 3683-3687

Received 6 December 1989/6 February 1990; accepted 16 February 1990 